\title{
FEATURES OF GROWTH AND DEVELOPMENT DYNAMICS OF LAUREL BRANCHES IN WEST GEORGIA (SAMEGRELO REGION) CONDITIONS
}

\author{
Kapanadze Sh. I. ${ }^{1}$, Kopaliani R. Sh. ${ }^{2}$ \\ Academic Doctor of Agrarian Sciences, Associate Professor, Agrarian Faculty ${ }^{l}$ \\ Doctor of Agricultural Sciences, Professor, Agrarian Faculty ${ }^{2}$ \\ Akaki Tsereteli State University, Kutaisi, Georgia
}

DOI: https://doi.org/10.31435/rsglobal_conf/30122020/7345

Abstract. The paper presents the results of a study, the aim of which was to determine the features of growth and development dynamics of Laurel plant branches in Samegrelo conditions. Studies have shown that the main branches of the Laurel are characterized by intensive growth, and the number of leaves varies according to the type of branches. Most of the leaves are on the main branches, and the least - on the side branches of previous and current year. Young branches of Laurel have active and relatively passive periods of growth. There are three or four periods during the whole vegetating, which does not happen on all types of branches at the same time.

Keywords: Young branches of Laurel, twigs, growth period, intensive growth, vegetation period.

Introduction. Scientists, specialists and farmers of subtropical regions, who grow such promising crops as tea, citrus fruits, noble laurel and other technical and fruit plants, make a great contribution to the development of the agrarian sector of Georgia. Laurel is an evergreen, xerophytic, drought and frost-resistant plant, it is combined well with other agricultural crops, plays an important role in the utilization of carbohydrates and in increasing oxygen (especially in Winter). Thus, the cultivation of laurel is of great importance in increasing the social and economic level of the rural population of the subtropical zone.

Noble laurel - Laurus nobilis L. Main commodity products derived from the plant: Dry leaf and essential oils of pleasant gentle aromas are widely used in various fields of national economy. Today, the demand for this product worldwide is much higher than the level of its production. However, it is increasing every year. Due to this, the world market is facing a problem with the supply line of laurel products.

Despite the results of researches conducted by Georgian scientists, today the laurel culture in Georgia is less time-consuming, gives great income, gets along well with other crops and promotes natural and labor resources rational use in subtropical farming, however, there are still many issues to be explored and clarified to improve various agricultural indicators. [1]

Purpose. We aimed to study the features of growth and development of laurel in the conditions of West Georgia (Samegrelo region). The obtained results will allow us to carry out further selection work, which is planned, in the direction of propagation and care of already selected high-oily forms of laurel.

Research methods. The research was conducted in a laurel plantation cultivated at Akaki Tsereteli State University Nosir Teaching Research Institute. We conducted determining the growth and development characteristics of the plants selected after the selection work, using commonly established methods according to phenological observations and biometric measurements. In Nosir training scientific-research farm, the soil is light clay at a depth of $20-40 \mathrm{~cm}$, with a weakly expressed granular-bony structure, it is higly moist, so drainage canals are arranged on the farm plot. According to the reaction, it is neutral, averagely provided with nutrients - nitrogen, potassium, phosphorus, the soil is low fertile according to the amount of humus. [1]
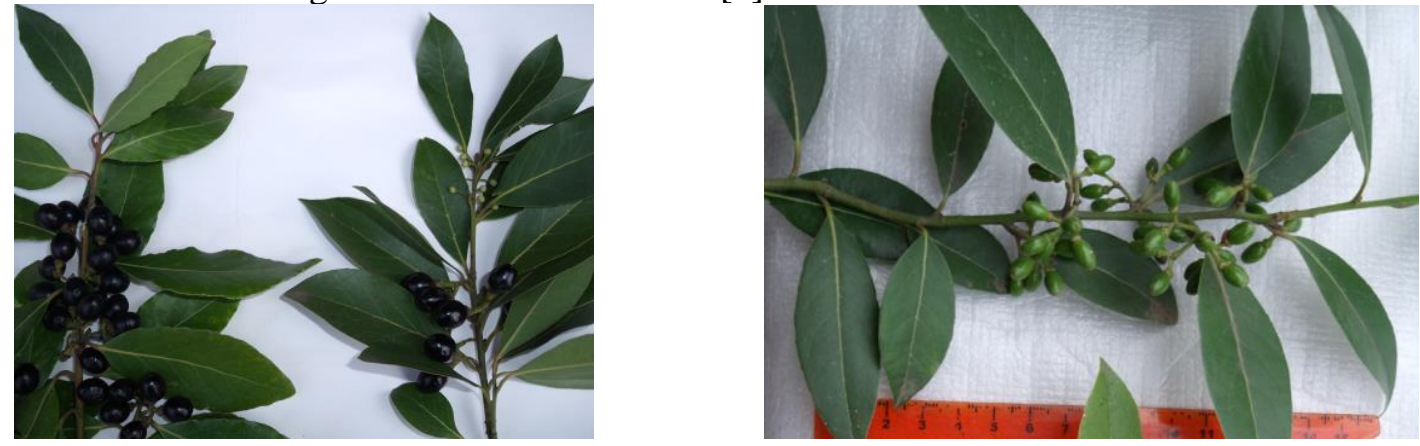
Results of researches. It is known that getting a high harvest of bay leaf highly depends on the growth and development of plant shoots. We studied the dynamics of shoot formation and its growth on one-two-year-old seedlings that developed during the first and second year of vegetation.

In order to study the growth characteristics of young laurel branches, we observed each decade and recorded from May to October - on 10,20 and 30. The branches measurements and leaves counting were conducted according to the types of branches, the condition of tip buds was also marked , 30-30 young branches were numbered on each bush, , from 1 to 10- tip growing branches, which grow on an annual growths from tip buds, from 11 to 20 , developed side branches from the side growths of previous year. Growth dynamics of young laurel branches during the first and second year of vegetation are given in Table1.

Table 1. Growth dinamics of young laurel branches according to months (I and II vegetation year after harvest, 2017-2019.)

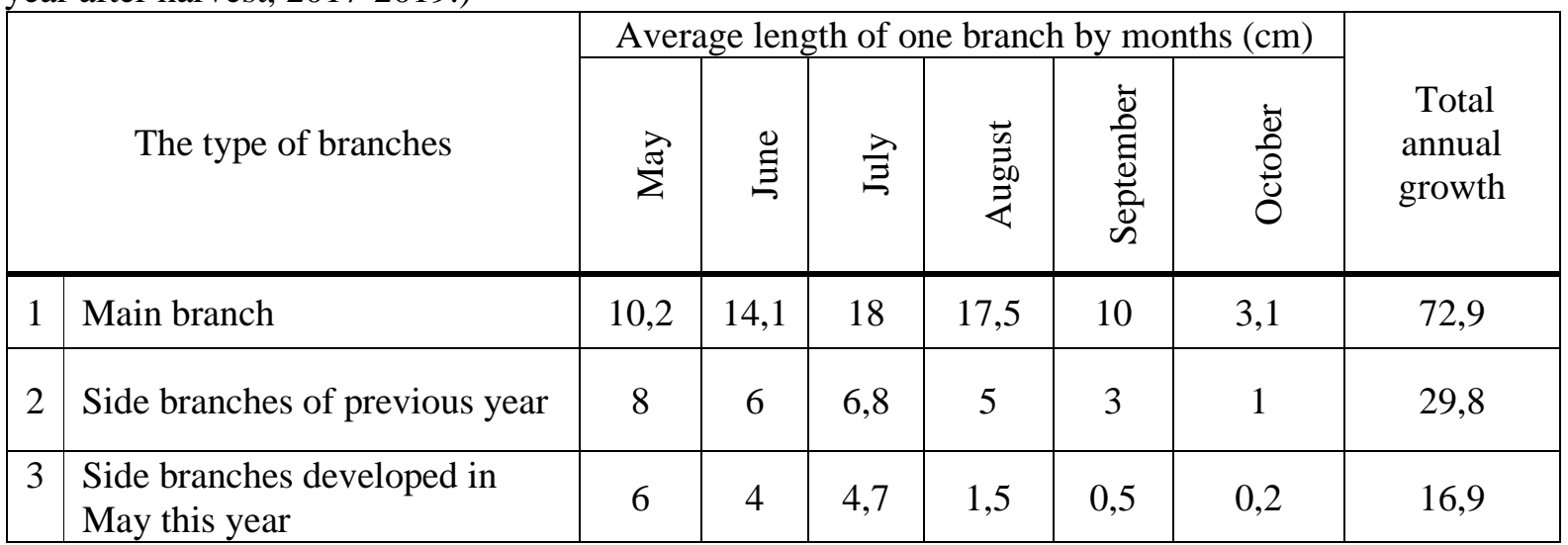

According to the Table, the main branches are mostly characterized by the strongest growth. With less growth - the previous year, and with a relatively weak growth - the side branches of the current year. The main branches give the maximum growth in July-August, the side branches of the previous (last) year - in June-July, and the branches developed in May of the current year - in MayJune. The annual growth of the main branches is about $73 \mathrm{~cm}$, last year's side branches $-30 \mathrm{~cm}$, and the current year's side branches $-17 \mathrm{~cm}$.

The growth marks of laurel branches by decades are given in Table 2, which shows that the growth of branches during the vegetation period does not stop in any decade, although the number of growing branches gradually decreases starting from May. This process is slightly observed in the main branches. Relatively obvious - in the side branches of the current year.

Table 2. The growth of young laurel leaves by decades (I and II vegetation year after harvest. The average of three years.)

\begin{tabular}{|c|c|c|c|c|c|}
\hline \multirow{3}{*}{ Month } & Decade & $\begin{array}{c}\text { Main } \\
\text { branch }\end{array}$ & $\begin{array}{c}\text { Side branches of } \\
\text { previous year }\end{array}$ & $\begin{array}{c}\text { Side branches of } \\
\text { current year }\end{array}$ & $\begin{array}{c}\text { Average according to } \\
\text { all types of branches }\end{array}$ \\
\hline \multirow{3}{*}{ May } & 2 & 3 & 4 & 5 & 6 \\
\hline & I & 2,5 & 1,6 & 1,6 & 1,9 \\
\cline { 2 - 6 } & II & 4,5 & 3 & 2,5 & 3,3 \\
\cline { 2 - 6 } & III & 4 & 2,5 & 2 & 2,8 \\
\cline { 2 - 6 } & average & 3,6 & 2,3 & 2 & 2,6 \\
\hline \multirow{4}{*}{ June } & I & 7 & 3,2 & 2,5 & 2,3 \\
\cline { 2 - 6 } & II & 4,5 & 2 & 1,2 & 3 \\
\cline { 2 - 6 } & III & 6 & 2 & 1 & 3,3 \\
\cline { 2 - 6 } & average & 5,8 & 2,4 & 1,5 & 3,8 \\
\hline \multirow{6}{*}{ July } & I & 7,5 & 2,5 & 1,5 & 3,6 \\
\cline { 2 - 6 } & II & 7 & 2,5 & 1,5 & 3,5 \\
\cline { 2 - 6 } & III & 6 & 2 & 1,3 & 3,3 \\
\cline { 2 - 6 } & average & 6,8 & 2,3 & 0,5 & 2 \\
\hline \multirow{4}{*}{ August } & I & 7,5 & 2 & 0,3 & 1,9 \\
\cline { 2 - 6 } & II & 5,5 & 0,5 & 0,4 & 2,4 \\
\cline { 2 - 6 } & III & 4,2 & 1,3 & & \\
\cline { 2 - 6 } & average & 5,7 & 1,3 & & \\
\hline
\end{tabular}


Continuation of table 2 .

\begin{tabular}{|c|c|c|c|c|c|}
\hline 1 & 2 & 3 & 4 & 5 & 6 \\
\hline \multirow{4}{*}{ September } & I & 4 & 0,5 & 0,5 & 1,6 \\
\cline { 2 - 6 } & II & 1,7 & 0,7 & 0,5 & 0,9 \\
\cline { 2 - 6 } & III & 2 & 0,8 & 0,2 & 1,7 \\
\cline { 2 - 6 } & average & 2,7 & 0,6 & 0,4 & 0,6 \\
\hline \multirow{4}{*}{ October } & I & 1,2 & 0,5 & - & 0,2 \\
\cline { 2 - 6 } & II & 0,6 & - & - & 0,2 \\
\cline { 2 - 6 } & III & 0,5 & 0,1 & - & 0,3 \\
\hline \multirow{2}{*}{$\begin{array}{c}\text { Totally during } \\
\text { vegetation } \\
\text { period }\end{array}$} & average & 0,7 & 0,2 & 17,4 & 39,7 \\
\hline
\end{tabular}

The average decadal growth of main branches is equal to 3,6 cm in May, 5,8 $\mathrm{cm}$ in June, 6,8 $\mathrm{cm}$ in July, 5,7 cm in August, 2,7 cm in September, and 0,7 cm in October. From the third decade of August, the height of the growth gradually decreases and reaches a minimum in October.

The average decadal growth of side branches last year is 2,3 cm in May-June and July, 1,3 cm in August, $0,6 \mathrm{~cm}$ in September. Decade growth of side branches last year has been gradually decreasing since the third decade of July, and growth in September is practically stopped.

The height of the average decadal growth on the side branches of the current year is equal to 2 $\mathrm{cm}$ in May, $1,5 \mathrm{~cm}$ in June, 1,3 cm in July, 0,4 cm in August. Growth gradually decreases from June and is practically stopped in August.

The developed number of leaves varies according to the type of laurel branches. Most ( 8 pieces) leaves are developed on the main branches, relatively few (4 pieces) on the side branches of the previous year, and fewer ( 2 pieces) on the side branches of the current year.

From the given materials, it is seen that the twigs grow throughout the vegetation period in the laurel leaf plantation, especially the main branches, which is due to the fact that after pruning, the plant tries to quickly restore the removed aboveground part. But this does not mean that all branches grew equally. They have alternating periods of relatively active growth with less active ones, which, in addition to environmental conditions, to some extent determines the beginning and end of a separate growth process, which according to all branches does not occur all at once and takes place gradually. With the completion of the first growth, the II growth begins almost imperceptibly in the third decade of May and the beginning of June; III - IV growth is observed in July-August and September, while in October the growth is mainly continued by the main branches, especially if the summer was dry and the rains started from September. Twig growth sometimes begins with undeveloped or poorly developed leaves even in good conditions. In such a case, the internodes are short, and during the period of active growth - long, the shortening of the internodes may be caused by unfavorable environmental conditions, which are not related to the beginning and end of growth.

Conclusions. Based on the given materials we can make the following conclusions:

1. The main branches are characterized by intensive growth, less growth - last year side branches, and relatively weak growth - side branches of the current year.

2. The number of leaves varies according to the type of branches, most of the leaves are on the main branches, and less - on the side shoots of the previous and current year.

3. Young laurel branches have periods of active and relatively passive growth. There are three or four periods in the vegetation period, which do not occur on all types of branches at the same time, and most of them are observed on the side branches.

\section{REFERENCES}

1. Kapanadze Sh. (2014), "Agrotechnology of noble laurel (Laurus nobilis L.) and correlation of genetically determined features with its productivity". Monograph. Akaki Tsereteli State University Publishing House. Kutaisi. https://opac.library.ac.ge/eg/opac/record/176696

2. Kopaliani, R., Kapanadze, Sh. (2018) "Laurel seedling growth and development dependence on seeding time in West Georgia conditions", International Academy Journal Web of scholar ISSN 2518-167X

1. DOI:https://doi.org/10.31435/rsglobal_wos, Vol 1, 10(28).

2. Kapanadze Sh., Kopaliani R., (2017) "The optimal time for planting a plantation of a highly oil-bearing form of Laurel noble by sowing seeds” Internauka: scientific journal. Moscow. № 5(9). 
3. https://elibrary.ru/contents.asp?id=34466526\&selid=28843688.

4. Kovacevic, N. N.; Simic, M. D.; Ristic, M. S., 2007. Essential oil of Laurus nobilis from Montenegro. Chemistry of Natural Compounds; Jul, Vol. 43 Issue 4, p408.

5. Mohammadreza Verdian-rizi. 2009. Variation in the essential oil composition of Laurus nobilis L. of different growth stages cultivated in Ira - Journal of Basic and Applied Sciences Vol. 5, No. 1, 33-36, ISSN: 1814-8085. Department of Pharmacognosy, Faculty of Pharmacy, Tehran University of Medical Sciences, Tehran, Iran.

6. Marzouki H., Elaissi A., Khaldi A., Bouzid S., Falconieri D., Marongiu B., Piras A. and Porcedda S. 2009. Seasonal and Geographical Variation of Laurus nobilis L. Essential Oil from Tunisia - The Open Natural Products Journal, 2, 86-91. 